\title{
TEACHER - STUDENT COMMUNICATION FROM PARENTS' PERSPECTIVE DURING ONLINE TEACHING IN THE TIME OF CORONA CRISIS
}

\author{
Andrej Maras \\ "Lotrščak" Primary School, Croatia
}

\begin{abstract}
COVID-19 virus, still relatively unknown to the general public, has taken over the world. The period of the coronavirus epidemic has affected all segments of life, including the education system. The traditional way of teaching (face to face) has been replaced by online teaching and a virtual environment through the mediation of information and communication technologies. The aim of this research is to gain insight into parents 'perceptions of teacherstudent communication during online teaching in the time of corona crisis. Fifteen parents of lower primary school students participated in the research. A semi-structured interview was used for data collection purposes. Participants' statements indicate that during online teaching students most often communicated with their teachers via e-mail, WhatsApp, Zoom, Google Classroom, and Teams. As one of the biggest advantages of communication during online teaching, participants stated the improvement of their children's digital competencies and introduction to various communication tools, while they said that the biggest disadvantage were technical difficulties. In order to improve communication between teachers and students during online classes, participants suggested that teachers use videoconferencing more often in their teaching and organize various discussions in virtual classrooms and online forums.
\end{abstract}

Keywords: communication, corona crisis, online teaching, parents, students.

\section{Introduction}

The pandemic caused by the COVID-19 virus has affected all aspects of life, including the education system. In order to control the spread of the pandemic, the Ministry of Science and Education of the Republic of Croatia issued a decision to close schools and the lives of adults and children have undergone significant changes. Teachers abandoned the usual methodological patterns of teaching and "moved" into a virtual environment while students followed classes online in their new virtual classrooms. The online form of teaching is a complex metacognitive and methodological - pedagogical process which, with its form and organization, clearly directs students towards achieving educational outcomes. Because of this specific virtual environment, it is especially important to establish two-way, productive and quality communication between the participants in the educational process, because such communication is a prerequisite for achieving educational 
outcomes. In the theoretical framework of this paper, communication features of online teaching will be presented and the pedagogical-methodical model of istance learning will be explained. The empirical research is focused on parents' experiences of communication between teachers and students during online teaching in the time of corona crisis.

\section{Distance Learning}

Distance learning is often identified with e-learning and computers, but it is important to note that distance learning appeared even before the first computers. The United States Distance Learning Association defines distance learning as the process of acquiring knowledge, skills and abilities through the provided instructions and information using various technological devices, i.e. the system and process of connecting students with distributed educational resources. Correspondence learning was initially associated with the postal system (1728) and was primarily intended for those who could not systematically follow classes and other courses (Sherry, 1996). Correspondence education is considered to be the first original form of distance learning. The beginnings of distance learning were characterised by sending books and other learning materials (audiocassettes, videotapes, CD-ROMs) with detailed instructions for self-study (Mayer, 2003). In distance learning educational outcomes can also be achieved through courses in which lectures are live-streamed via radio or television or through recorded materials (Savić, 2006). At the end of the $20^{\text {th }}$ century distance learning has been enriched with computers that have greatly facilitated the evaluation of students' work and enabled faster feedback (Matijević \& Radovanović, 2011). Such technological advances in distance learning have enabled learning through teleconferencing, i.e. video conferencing that creates the illusion of a real class by participating in discussions and sharing learning materials between students (Radosav, 2005). Although the advent of computers has greatly facilitated online teaching and enabled two-way communication, today we are facing other problems during its implementation. Authors Jokić and Ristić-Dedić (2020) conducted a research on the experiences and satisfaction with online teaching of $7^{\text {th }}$ grade students. The research conducted by the Institute for Social Research in Zagreb included 23 (randomly selected) primary schools in the City of Zagreb, i.e. 923 students. The research results indicate that the average grade for online teaching is 3.14 (on a scale from 1 to 5), with the dominant attitude being that students are "neither satisfied nor dissatisfied" with online teaching. As many as $71 \%$ of students believe that they are overwhelmed with this form of teaching, but the research finds that $88 \%$ of students agree with the statement that they use digital devices with ease, of which $61.5 \%$ completely agree. Online teaching takes place in a more complex environment than the classic form of teaching. In order 
for a student to be productive and successfully respond to the demands of online teaching, it is important to manage three main (perception, emotions, selfregulation) and nine specific personal and practical skills and abilities: selfawareness, internet skills, motivation, beliefs, anxiety, self-perception, concentration and time management (Meng Jung, 2009). We can conclude that these skills and abilities are developmental and are developed through experience, so teachers should certainly adjust their expectations and be more flexible during online classes. It is extremely important to keep in mind that students are in a developmental phase in which it is necessary to encourage the development of these skills and accordingly adjust some educational requirements of online teaching (Monavar Yazdi \& Zandkarimi, 2013).

\section{Terminological Definition of E - learning}

Electronic learning during the teaching process presupposes the implementation of information and communication technology, i.e. learning contents are supported by strategically designed computer applications (Kovačević, 2016). The challenges of modern society and technological development have encouraged the use of digital platforms in the education system. Relying on the Recommendations of the European Parliament for lifelong learning (2006), the learning competence as one of the basic competences is inseparable from the digital competence. In modern society, digital media have an equally important role in the learning process as once had the only medium, except for teachers, and that is a textbook in the book form (Matijevic \& Topolovčan, 2017). The two basic types of e-learning are a computer-assisted learning process and web-based learning. Computer-assisted learning implies an individual form of learning in which an individual uses certain learning programs with the help of the media and computers. Web-based learning refers to various online ways of learning such as forums, webinars, virtual lectures and the like. This form of learning involves learning in a virtual learning environment (VLE) and relies on interactive information systems and other users (Piskurich, 2003). If we look at the process of e-learning development throughout history, we notice that analogue media such as television, radio, gramophone and film projector prevailed, while today we are seeing digital devices such as computers and mobile devices. It is important to note that new technologies complement the old ones, put them in a new form and new format and they do not contradict, but complement each other (Macdonald, 2008). By analysing the recent literature, we can conclude that there are numerous controversies about the advantages and disadvantages of e-learning. Some authors state that the biggest advantage of elearning is the independence of the place and time of teaching as well as personalization when creating teaching content and its availability. Furthermore, 
they mention efficiency as an advantage because the teaching contents can be reproduced several times and also the dynamism of the teaching process. On the other hand, a significant disadvantage of e-learning is the need to have equipment and access to Internet websites as well as social isolation that can lead to a lack of motivation to learn. Furthermore, the successful implementation of e-learning significantly depends on the motivation and knowledge of teachers regarding the didactic design of media teaching content (Jukić, 2017).

\section{Synchronous and Asynchronous E-learning}

Depending on the time and place of the e-learning process, it can be synchronous and asynchronous. Synchronous learning takes place in real time with the possibility of simultaneous interaction between students and teachers. In synchronous learning, students sign in using the learning program or the website at a specific time in which classes are scheduled to begin. Thanks to computer programs and network connection, synchronous learning is characterized by twoway communication in which students can ask questions to their teacher, but they can also participate in discussions. Asynchronous learning involves using content when it suits users most. It is not controlled by time, place, or cooperation (Macdonald, 2008). Considering the possibilities and limitations of e-learning, we can conclude that e-learning takes part in building a culture of critical thinking and research and opens the way for creativity in the teaching process. Also, knowing the methodological and didactic possibilities of information and communication technology in the teaching process, it is important to emphasize that they must not endanger the originality of teaching and interaction between its participants (Mušanović, 2000).

\section{Communication during Online Teaching}

Communication as the key to education is the foundation of successful teaching and all interpersonal relationships. Due to its complexity, it is impossible to unambiguously define communication. Authors Jukić and Nadrljanski (2015) define communication as a complex human activity that is the basis of human action and involves the exchange of messages between one or more persons as a basic human need. If we look at modern teaching as an interactive process, we conclude that communication skills are key to achieving the desired educational outcomes. The National Framework Curriculum (2011) emphasizes social competence as a prerequisite for lifelong learning to which modern education aspires. Communication during online teaching is especially challenging for both 
teachers and students. The authors Smith, Ferguson and Caris (2002) conducted a study examining communication features of online teaching and traditional teaching from the perspective of teachers $(\mathrm{N}=21)$. All interviewed teachers worked in both teaching models, so it was easier to compare specificities. The results showed that online teaching required more work from teachers regarding the preparation of lessons, but also the way they taught those lessons. The authors explain these results by the fact that all teaching content must be prepared and available in writing form, and the teacher is required to systematically check students' work, evaluate it and be constantly present in order to answer questions and resolve ambiguities. Also, teachers pointed out that it was especially difficult for them to communicate with students because they had to try hard to work effectively without the possibility of control the class with direct eye contact. On the other hand, they saw many advantages of this form of teaching. Teachers noticed that students were more active in organized written discussions than in the classical form of teaching because they were not limited by time or space. The authors point out that this form of communication and work gives students a sense of freedom from authority and pressure from teachers. Scientists point out that face-to-face communication is easier and much more rewarding for teachers than communication during online teaching. In the classroom, the teacher is an inexhaustible source of information while in a virtual environment such communication is often limited (Woods, 2002). The authors emphasize that it is crucial that teachers find the communication channel that best suits their students during online lessons in order to create a comfortable and motivating atmosphere in which each student will succeed (Coppola, Hiltz \& Rotter, 2002). Furthermore, the virtual environment requires teachers to step out of their comfort zone of communication and learn new communication tools to make students in the virtual classroom feel welcomed, safe and successful (Grant \& Thornton, 2007). During the teaching in a virtual environment, it is especially important that the teacher is the initiator and organizer of various discussions in educational forums in order to further connect students. The authors point out that it is important to create a communication network in order to achieve the best possible learning goals (Palloff and Pratt, 2005). Twenty years ago, the authors Matijević, Rijavec and Drandić (1997) pointed out that research that dealt with communication during distance education often indicates the problem of "personal isolation" of participants during autodidactic activities. The authors Buza and Hysa (2020) investigated what communication tools high school teachers used to enhance school-family collaboration during the corona crisis. Research has shown that teachers have used different forms of indirect communication using Viber, Zoom and the phone. Research by Bhamani et al. (2020) conducted a survey on a sample of 19 parents about online teaching experiences during corona crisis. Research has shown that some Pakistani schools have skillfully communicated with parents 
via Viber, WhatsApp and other platforms while some mothers have created Facebook pages to make it easier to communicate with other parents. Teachers organized classes using the Zoom platform or Google Classroom, and students were very successful in taking notes during online classes.

\section{Research Methodology}

The aim of this research is to gain insight into parents' perceptions of teacher-student communication during online teaching in the time of corona crisis. In line with that objective, the following research questions were asked:

1. Which communication channels did teachers most often use in communicating with their students during online classes?

2. What advantages and disadvantages do parents notice regarding communication between teachers and students during online classes?

3. What are parents' suggestions for improving communication between teachers and students during online classes?

Fifteen parents of lower primary school children from the city of Zagreb participated in the research. Each of the mentioned families has at least one personal computer at home. A non-probability snowball sampling technique was used. Three randomly selected primary schools were included in the research. Each school is equipped with an ICT classroom and has a single computer in all other classrooms. The research was conducted in November 2020 and March 2021. The research referred to the implementation of online classes in the period from March 16, 2020 to April 25, 2020. For the purpose of data collection, a semistructured interview method was used, which consisted of ten open-ended questions. An individual interview with each of the fifteen participants was conducted and they were recorded with a Dictaphone with the prior mentioned participants' written consent. Each interview required preparing the interviewer and informing the participants about the aim and purpose of the research, their anonymity, and the possibility of giving up at any time. The qualitative data analysis was performed by coding in the NVivo program, and the results were presented by descriptive method.

\section{Results and Discussion}

After the author had coded the data, they were classified into the following topics: Communication channels in communication between teachers and students during online teaching, Advantages and disadvantages of communication in a virtual environment, Parents' suggestions for improvement of communication during online teaching. 
Topic: Communication channels in communication between teachers and students during online teaching.

Participants cite email, WhatsApp, Zoom, Google Classroom and Teams as the most common communication channels used by teachers to communicate with their students. These statements are confirmed by the NCVVO - National Centre for External Evaluation of Education (2020) survey on a sample of $(\mathrm{N}=13,099)$ Croatian high school graduates which showed that they communicated most with teachers using e-mail, WhatsApp, Zoom and Teams.

One participant pointed out that his son communicated with the teacher exclusively via e-mail and expressed dissatisfaction with this form of communication, emphasizing that the teacher seemed distant and indifferent. This is his statement:

"In such a difficult situation, especially for children, I expected more understanding from the teacher. It would help my son a lot. I often had the impression that the teacher was cold and distant, as if she was not particularly interested in this form of teaching."

Such a statement should not be surprising. Teachers who communicate with their students via e-mail during online classes should have good communication skills, but they should also be cautious. A short e-mail, with very few instructions on how to do assignments, can be interpreted by the student as a teacher's lack of interest for his or her work (Coppola, Hiltz \& Rotter, 2002).

Participants especially praised the teachers who organized virtual classroom meetings on the Zoom platform. Here are some of the statements:

"My daughter was jumping with joy around the apartment hearing that she was going to have a virtual homeroom class. That really helped her. I will never forget the look of her face when she saw her classmates.”

"A homeroom Zoom class is the best thing the teacher could think of. Everyone was excited, and the teacher listened to them patiently and dedicated his time to each child. They really needed it."

"A homeroom Zoom class was a real pleasure for the whole family."

One participant pointed out that his daughter was particularly enthusiastic when the teacher explained the new curriculum content via videoconference, but that happened very rarely.

"I was particularly impressed by this communication channel because I could see my daughter actively participating during online lessons, but also developing her digital competence.”

This statement is related to Doggett's research (2008) which examined the satisfaction of students with online teaching via videoconference. It was found that $90 \%$ of the students were satisfied with the way the teacher gave the lecture, they felt as part of the teaching process and asked questions and participated as if they were physically present. 
Topic: Advantages and disadvantages of communication in a virtual environment

Advantages:

Thirteen out of fifteen participants pointed out that the biggest advantage of communication during online teaching was that children had the opportunity to improve their digital competence and adopt rules of decent behavior in a virtual environment, but they could also become familiar with new communication tools. Here are some of the statements:

"I am glad that my daughter has learned the rules of polite communication in a virtual environment."

"My son was introduced to new teaching methods and communication tools, but also developed his digital competence."

These statements on how their children improved their digital competence while communicating with teachers during online classes are confirmed by the research of Jokić and Ristić-Dedić (2020) with seventh grade students $(\mathrm{N}=923)$. $88 \%$ of them said that they considered themselves competent to use digital devices.

Disadvantages:

All participants stated that the biggest disadvantage of communication during online classes was the inability to read nonverbal cues of the participants and the lack of face-to-face communication.

"My son often pointed out that he lacked direct communication with his teacher, especially his body language which has a calming and motivating effect on him.”

This statement can be based on the knowledge that it is through non-verbal communication that teachers draw attention to themselves and their subject of teaching, they motivate and direct students and thus they positively affect students' educational achievements (Najafi \& Rahmanzade, 2013).

"Many times I have heard my daughter complain because she did not understand the new teaching contents due to the lack of direct communication with the teacher."

These statements are confirmed by the NCVVO (2020) survey on a sample $(\mathrm{N}=13,099)$ of Croatian high school graduates. It was found that $90 \%$ of students had difficulty mastering the curriculum due to lack of direct communication with the teacher.

Six participants pointed out that their child had technical difficulties with the Internet connection during online classes. Here are some of the statements:

"My son would be very upset when the Internet connection broke." 
"I remember my daughter crying because her Internet connection broke during the exam."

The NCVVO survey (2020) also indicated the occurrence of technical difficulties during online teaching. It was found that $60 \%$ of students, to a greater or lesser extent, had difficulties with the Internet. They also found that $35 \%$ of students do not have their own computer.

Topic: Parents' suggestions for improvement of communication during online teaching

Seven participants pointed out that, in order to improve communication during online lessons, it would be useful for teachers to use videoconferencing more often when teaching new content.

"I think that videoconferencing would be extremely useful in presenting new teaching content."

"I believe that videoconferencing could stimulate class discussion and thus make online teaching more interactive and dynamic."

The statements of how teachers rarely used videoconferencing during online classes are also confirmed by the NCVVO (2020) survey conducted on a sample $(\mathrm{N}=25,000)$ of parents of fifth and seventh grade students. The results indicate that as many as $70 \%$ of students communicated with teachers only via smartphone apps and e-mail, while only $20 \%$ of parents claimed that teachers communicated directly with their children, for example by videoconference or via Skype.

Eight participants pointed out that communication between teachers and students could be improved if teachers organized various discussions in virtual classrooms and forums. They pointed out that they are aware that the forum is intended for older primary school students and that this form of asynchronous communication could suit students who express themselves better in writing.

"Forum discussions would also encourage shy and reserved students, like my daughters, to participate in the teaching process"

"If teachers used educational forum discussions, students could help each other with learning and homework difficulties."

These statements really deserve to be considered closely. Research by Ellis (2001) shows us that a forum is an excellent form of asynchronous communication during online teaching. It is suitable regarding the place and time of lessons and it is more appropriate for reserved students who can express themselves better this way. Furthermore, published messages remain stored and users can re-read them at any time. This communication tool gives students some time to think and compose a post. The teacher takes on the role of moderator and students are actively encouraged to research independently. 


\section{Conclusion}

In scientific terms, the results presented here will contribute to a better understanding of the specific communication features of the virtual environment, but also of information and communication technologies in the teaching process. In terms of methodological limitations of this research, in the Republic of Croatia there is a very small number of previous online learning research, statistics and experiences of all those who share responsibility for the upbringing and education of children and youth. Furthermore, this research included only three primary schools and parents from urban areas, but the inclusion of primary schools and parents from rural areas would provide more relevant data and a broader picture regarding the advantages and limitations of online teaching. The specificity of urban and rural environment in terms of the employment rate of parents and the technical equipment of households would certainly affect the results of the research. This research will certainly serve as a basis for further research on the opportunities, challenges and shortcomings of the communication between teachers and students during online lessons. From the parents 'perspective, teachers most often communicated with students via email, WhatsApp, Zoom, Google Classroom and Teams, while only some teachers, but very rarely, used videoconferencing. As the biggest advantage of communication during online teaching, participants pointed out the opportunity that the children had to improve their digital competencies, to adopt rules of decent behavior in a virtual environment, but also to become familiar with new communication tools. As a key shortcoming, they stated the inability to read nonverbal cues, a lack of faceto-face communication, and technical difficulties with the Internet. Seven participants thought that communication between students and teachers would be more successful if teachers used videoconferencing more often in their teaching, while eight participants pointed out that communication between teachers and students could be improved if teachers organized various discussions in virtual classrooms and forums.

\section{References}

Bhamani, S., Makhdoom, A. Z., Bharuchi, V., Ali, N., Kaleem, S., \& Ahmed, D. (2020). Home learning in times of COVID: Experiences of parents. Journal of Education and Educational Development, 7(1), 9-26. doi: http://dx.doi.org/10.22555/joeed.v7i1.3260

Buza, V., \& Hysa, M. (2020). School-family cooperation through different forms of communication in schools during the Covid-19 pandemic. Thesis, 9(2), 55-80.

Coppola, N. W., Hiltz, S. R., \& Rotter, N. G. (2002). Becoming a virtual professor: Pedagogical roles and asynchronous learning networks. Journal of management information systems, 18(4), 169-189. doi: https://doi.org/10.1080/07421222.2002.11045703

Doggett, A.M. (2008). The Videoconferencing Classroom: What Do Students Think? Journal of industrial teacher education, 44(4), 29-41. 
Ellis, A. (2001). Student-centred collaborative learning via face-to-face and asynchronous online communication: What's the difference? In ASCILITE (str. 169- 178). Melbourne: Faculty of Information Technology Monash University.

Grant, M. R., \& Thornton, H. R. (2007). Best practices in undergraduate adult-centered online learning: Mechanisms for course design and delivery. Journal of online Learning and Teaching, 3(4), 346-356.

Jokić, B., \& Ristić-Dedić, Z. (2020). Zadovoljstvo učenika nastavom na daljinu Retrieved from https://www.index.hr/vijesti/clanak/kako-su-ucenici-ocijenili-online-nastavu-borisjokicproveo-istrazivanje/2189258.aspx

Jukić, D. (2017). Tehnička pripremljenost i motiviranost studenata hrvatskih sveučilišta za online oblik nastave. Život i škola: časopis za teoriju i praksu odgoja i obrazovanja, 63(1), 93-102.

Jukić, S., \& Nadrljanski, M. (2015). Komunikologija. Split: Redak.

Kovačević, S. (2016). Jadranka Lasić-Lazić (Ed.), Informacijska tehnologija u obrazovanju. Znanstvena monografija. Društvena istraživanja, 25(2), $\quad$ 280-284. doi:https://doi.org/10.5559/di.25.2.09

Macdonald, J. (2008). Blended learning and online tutoring: Planning learner support and activity design. Aldershot, UK: Gower.

Meng-Jung, Tsai. (2009). The Model of Strategic e-Learning: Understanding and Evaluating Student e-Learning from Metacognitive Perspectives. Journal of Educational Technology \& Society, Knowledge infrastructure of the future, 12(1), 34- 48. International Forum of Educational Technology \& Society. Retrieved from https://eric.ed.gov/?id=EJ833415

Matijević, M., \& Radovanović, D. (2011). Nastava usmjerena na učenika Zagreb: Školske novine.

Matijević, M., \& Topolovčan, T. (2017). Multimedijska didaktika. Zagreb: Školska knjiga.

Matijević, M., Rijavec, M.\& Drandić, B. (1997). "Secondary school students in Croatia and Internet”, MIPRO - Multimedia and Hypermedia systems. $20^{\text {th }}$ Interantional Convention, Opatija, Croatia, p. 110-114.

Monavar Yazdi, S., \& Zandkarimi, G. (2013). The Impact of E-Learning on some Psychological Dimensions and Academic Achievement. International Journal of Education and Learning 2(2), 49-56. doi: http://dx.doi.org/10.14257/ijel.2013.2.2.05

Mušanović, M. (2000). Postmoderna pedagogija i virtualna stvarnost. In V. Rosić (Ed.), Nastavnik i suvremena obrazovna tehnologija. Zbornik radova s međunarodnoga znanstvenoga kolokvija, 11-18. Rijeka: University of Rijeka, Department of Pedagogy.

Mayer, R. (2003). The promise of multimedia learning: using the same instructional design methods across different media. Learning and Instruction, 13(2), 125-139.

Nacionalni centar za vanjsko vrednovanje obrazovanja (NCVVO). (2020). Ispitivanja o iskustvima i zadovoljstvu nastavom na daljinu. Retrieved from: NCVVO_Ispitivanja-onastavi-na-daljinu.pdf (kinstacdn.com)

Nacionalni okvirni kurikulum. (2011). Zagreb: Ministarstvo znanosti, obrazovanja i športa RH. Retrieved from: Nacionalni_okvirni_kurikulum.pdf (mzos.hr)

Palloff, R., \& Pratt, K. (2005). Online learning communities revisited. In 21st annual conference on Distance Teaching and Learning, (pp. 3-5).

Piskurich, G. M. (2003). Editor's introduction: What is e-learning?. In G. M. Piskurich (Ed.), The AMA handbook of e-learning: Effective design, implementation, and technology solutions. pp1-10. New York: AMACOM.

Radosav, D. (2005). Obrazovni računarski softver i autorski sistemi . Novi Sad: University of Novi Sad. 
Maras, 2021. Teacher - Student Communication From Parents' Perspective During Online Teaching in The Time of Corona Crisis

Savić, A. (2006). Metode razvoja i primjena XML web servisa kao podrska tradicionalnom obrazovnom procesu (Doctoral dissertation). University of Novi Sad.

Sherry, L. (1996). Issues in Distance Learning. London: Tivoli books.

Smith, G. G., Ferguson, D., \& Caris, M. (2002). Teaching on-line versus face-to-face. Journal of Educational Technology Systems, 30(4), 337-364. doi: https://doi.org/10.2190/FFWXTJJE-5AFQ-GMFT

Woods Jr, R. H. (2002). How much communication is enough in online courses? -exploring the relationship between frequency of instructor-initiated personal email and learners' perceptions of and participation in online learning. International Journal of Instructional Media, 29(4), 377. 